\title{
Patient with tuberculous flexor tenosynovitis of the hand
}

\author{
Sibashish Panigrahi, ${ }^{1}$ Mantu Jain (10 , ${ }^{1}$ Ritesh Panda (D) , \\ Lubaib Karaniveed Puthiyapura'
}

${ }^{1}$ Orthopaedics, AllMS Bhubaneswar, Bhubaneswar, Orissa, India

${ }^{2}$ Trauma and Emergency, AllMS Bhubaneswar, Bhubaneswar, Orissa, India

Correspondence to

Dr Mantu Jain;

montu_jn@yahoo.com

Accepted 4 May 2021

Check for updates

(c) BMJ Publishing Group Limited 2021. No commercial re-use. See rights and permissions. Published by BMJ.

To cite: Panigrahi S, Jain $M$, Panda $\mathrm{R}$, et al. BMJ Case Rep 2021;14:e243091. doi:10.1136/bcr-2021243091

\section{DESCRIPTION}

Chronic flexor tenosynovitis of the hand is a rare condition in the present time. ${ }^{1}$ Tuberculous tenosynovitis of the wrist is generally called compound palmar ganglion though ganglion is a misnomer. ${ }^{1}$ It constitutes $5 \%$ of the total bone and joint tuberculosis infection. ${ }^{1}$ It presents with swelling of long duration with dull aching pain and few other symptoms at a very later stage. The most commonly affected sites are the ulnar or radial bursae of the hand. ${ }^{12}$ In $80 \%$ of the population, these bursae are interconnected, giving rise to horseshoe-shaped tenosynovitis. ${ }^{3}$ These are difficult to diagnose and excise at very late presentation. ${ }^{4}$ Here we present a similar case report which was diagnosed and treated successfully at our centre.

Case: A 50-year-old man presented to us with swelling over his left wrist and palm. The patient is a butcher by profession and works in a fish market. Initially, the swelling was small and painless, not associated with fever, night sweats, cough, weight loss and trauma, and the patient had no contact with anyone with tuberculosis. But in due course of time over the last 4 years, it increased in size involving the wrist, hypothenar eminence and little finger base. The patient had intermittent mild pain and discomfort with restriction in the little finger's terminal flexion (distal interphalangeal joint). $\mathrm{He}$ had tingling sensation and paraesthesia over the distribution region of the median nerve. It was more in the night. On examination of the swelling, it was an hourglass swelling, soft and doughy, crossfluctuant and strong; gritty crepitus was palpable on the movement of fingers (figure 1A). The X-rays of the wrist, hand and chest were normal with only local soft tissue shadow and no bony abnormality. The patient had a scar over the ulnar aspect of palm because before presenting to us, he had undergone a needle aspiration somewhere else. The culture report was sterile. We did an MRI scan of the hand, which showed thickened synovium with internal T2 hypointense foci surrounding the flexor tendon (figure 1B,C). Haematological work-up revealed normal counts. Erythrocyte sedimentation rate was 20. The total leucocyte count was 8200. Mantoux test was negative.

After all the necessary investigations, an excisional biopsy was planned for the tenosynovium. Under a tourniquet, through a volar approach, the ulnar aspect's flexor tenosynovium was explored after incising the subcutaneous tissue and aponeurosis (figure 2A,B). Gross swollen tenosynovium was found ulnarly at the wrist, hypothenar area, and the swelling was continuing until the fifth finger's base. Carpal tunnel was cut and released in view of median nerve decompression. After careful dissection and taking care of the neurovascular structures, radical excision of the synovial sheath of tendons was done. Caseating fibrinous materials, amber-coloured fluids with melon seed bodies and rice bodies were found in abundance. The flexor superficialis tendon of the little finger was found adherent to the inflamed synovium, so it was sacrificed. The tissue was sent for biopsy (figure 2C). Intraoperative findings were corroborative of compound palmar ganglion. The wound was closed in layers after thorough washing. A volar cock-up splint was applied for 2 weeks. Finger movements were encouraged from day 2. Histopathology examination confirmed tuberculosis, and anti-tubercular therapy was started. At 6 months of follow-up, the patient did not have a recurrence in swelling, and the wrist and finger movements were normal.

Extrapulmonary tuberculosis involves mainly lymph nodes, bones, joints, gastrointestinal tracts, tendon sheaths, etc. ${ }^{5}$ Tuberculosis of the synovial sheath of flexor tendons of hands involving the radial or ulnar bursa is rare but not uncommon. ${ }^{46}$ Dominant upper limb is most commonly involved. ${ }^{7}$ Men are affected more and those who are generally farmers, labourers or involved in animal husbandry. ${ }^{18}$ Tuberculous tenosynovitis is caused due to haematogenous spread from a primary focus of infection or by direct inoculation from adjacent infected tissue. ${ }^{9}$ The progression of disease is slow and insidious. Initially, the symptoms are minimal. There is mild swelling around the wrist initially, which involves the adjacent areas over few months to years. Most of the patients present with a dumbbell-shaped swelling across both sides of the flexor retinaculum with a positive cross fluctuation test. ${ }^{1}$ They come very late for medical advice after the development of pain, discomfort, median nerve compression symptoms, ${ }^{10}$ and restrictions of movement of fingers or wrists. Local signs of inflammations are very minor, ${ }^{8}$ and have three stages. ${ }^{7}$

Stage 1 (hygromatous): increased synovial exudates inside the sheath is found.

Stage 2 (serofibrinous): caseous debris and fibrous tissue replace the exudates (rice and melon seed bodies).

Stage 3 (fungoid): extensive caseation and sinus formation with bone and joint involvement.

These types of swelling have a large category of differential diagnoses like pyogenic tenosynovitis, fungal infection, rheumatoid arthritis, gouty 

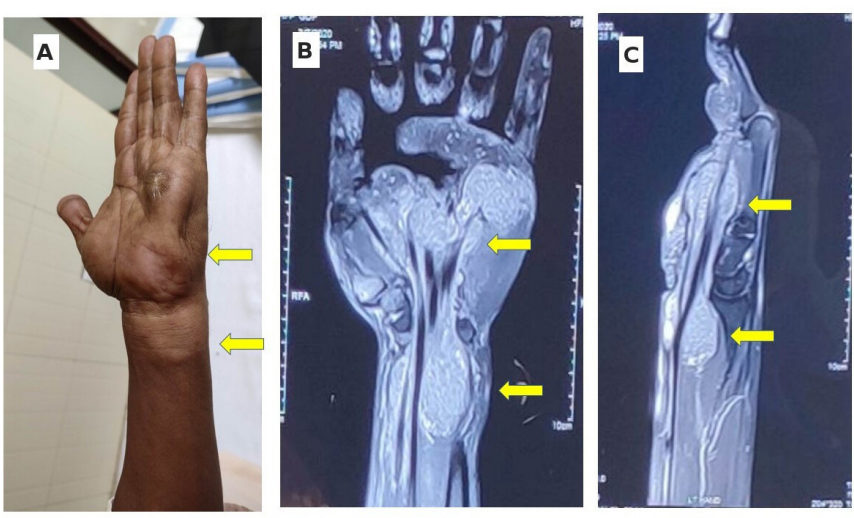

Figure 1 (A) Clinical images showing ganglion on either side of wrist (arrow marked). The same can also be seen in the coronal (B) and sagittal (C) cut MRI as T2 hypointense foci surrounding the flexor tendon sheath in the palmar region and distal forearm (arrow marked).

arthritis, infected ganglion, foreign body reaction granuloma, pigmented villonodular synovitis, sarcoidosis, brucellosis, systemic lupus erythematosus, etc. ${ }^{11} 12$ Radiograph of local region is usually normal, unless in a later stage when the chronic mass effect causes bone erosion. Ultrasonography is a cost-effective, easy and early non-invasive diagnostic modality. It shows an increased volume of synovial tendon sheath with a fluid collection. MRI is the gold standard of investigation because of its excellent soft tissue delineation. ${ }^{13} \mathrm{~T} 2$-weighted images give a nice depiction of fluid content inside synovium with a mixed solid cystic constituency. Gadolinium-enhanced imaging can also be done. MRI shows the extended abscess formation and spread of inflammation. ${ }^{13}$ Histopathology of synovial tissue reveals granulomatous lesions with central caseation surrounded by multiple giant cells and epithelioid cells. Characteristic 'rice bodies' or 'melon seed bodies' are found inside the synovial sheaths of tendons. ${ }^{12}$ They are soft, elastic and spongy in a constituency that floats in synovium after the inflammatory stage. These are believed to be synovial fringes or villous subendothelial vascular connective tissue processes covered by endothelium, which detaches from the sheath by gradual movements of tendons
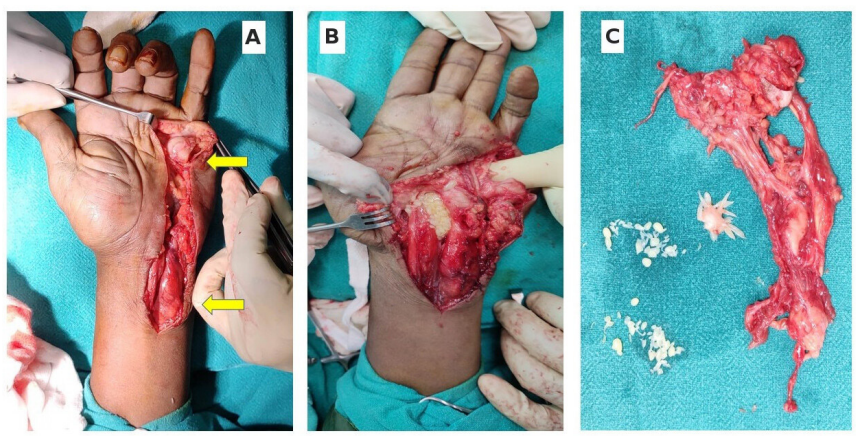

Figure 2 (A) Intraoperative findings showing the two ends of dumbbell ganglion (arrow marked); the rice bodies are seen in situ (B) and after excision (C) with cyst wall. and remains inside tenosynovium. There is the precipitation of fibrin over these bodies. Four chemotherapy drugs (rifampicin, isoniazid, pyrazinamide, ethambutol) are recommended for 12 months following diagnosis and radical tenosynovectomy. ${ }^{4}$ Still, recurrence is common. ${ }^{6}$

\section{Learning points}

- Tubercular tenosynovitis (compound palmar ganglion) is rare in present times.

- Rice bodies or melon seeds are commonly formed and abundantly found.

- It is easy to diagnose but often neglected leading to carpal tunnel syndrome.

Acknowledgements The radiology department of our institute for giving us the MRI pictures.

Contributors All authors were involved in the diagnosis and management of patients. LKP was the main person involved in the follow-up. SP and MJ wrote the paper and RP and LKP gave critical inputs. All authors agree to the content of the manuscript.

Funding The authors have not declared a specific grant for this research from any funding agency in the public, commercial or not-for-profit sectors.

Disclaimer Case reports provide a valuable learning resource for the scientific community and can indicate areas of interest for future research. They should not be used in isolation to guide treatment choices or public health policy.

Competing interests None declared.

Patient consent for publication Obtained.

Provenance and peer review Not commissioned; externally peer reviewed.

\section{ORCID iDs}

Mantu Jain http://orcid.org/0000-0003-3848-4277

Ritesh Panda http://orcid.org/0000-0001-5588-5692

\section{REFERENCES}

1 Wali H, Al-Khuwaitir S, Hafeez MA. Compound palmar ganglion: a case report and literature review. Ann Saudi Med 1986;6:55-8

2 Demir M, Küçük L, Mermut G. El bileği fleksör tendonlarında tüberküloz tenosinoviti [Tuberculous tenosynovitis in wrist flexor tendons]. Tuberk Toraks 2019;67:236-8.

3 Pimm LH, Waugh W. Tuberculous tenosynovitis. J Bone Joint Surg Br 1957;39B:91-101.

4 Beam E, Vasoo S, Simner PJ, et al. Mycobacterium arupense flexor tenosynovitis: case report and review of antimicrobial susceptibility profiles for 40 clinical isolates. J Clin Microbiol 2014;52:2706-8.

5 Higuchi S, Ishihara S, Kobayashi $\mathrm{H}$, et al. A mass lesion of the wrist: a rare manifestation of tuberculosis. Intern Med 2008;47:313-6.

6 Sbai MA, Benzarti S, Boussen M, et al. Tuberculous flexor tenosynovitis of the hand. Int J Mycobacteriol 2015;4:347-9.

7 Tuli SM. Tuberculosis of the skeletal system: bone, joints, spine, and bursal sheaths. 3 edn. New Delhi: Jaypee Brothers Medical Publishers, 2004.

8 Baidoo PK, Baddoo D, Ocloo A, et al. Tuberculous tenosynovitis of the flexor tendons of the wrist: a case report. BMC Res Notes 2018;11:238.

9 Hooker RP, Eberts TJ, Strickland JA. Primary inoculation tuberculosis. J Hand Surg Am 1979;4:270-3.

10 Altaf W, Attarde D, Sancheti P. Tubercular compound palmar ganglion presenting as a severe carpal tunnel syndrome- a case report. J Clin Orthop Trauma 2020;11:S889-91.

11 Walker UA, Gutfleisch J, Peter HH. Case number 23: tuberculous tenosynovitis. Ann Rheum Dis 2002;61:384.

12 Woon CY-L, Phoon E-S, Lee JY-L, et al. Rice bodies, millet seeds, and melon seeds in tuberculous tenosynovitis of the hand and wrist. Ann Plast Surg 2011;66:610-7.

13 Hsu C-Y, Lu H-C, Shih TT-F. Tuberculous infection of the wrist: MRI features. AJR Am J Roentgenol 2004;183:623-8. 
Copyright 2021 BMJ Publishing Group. All rights reserved. For permission to reuse any of this content visit https://www.bmj.com/company/products-services/rights-and-licensing/permissions/

BMJ Case Report Fellows may re-use this article for personal use and teaching without any further permission.

Become a Fellow of BMJ Case Reports today and you can:

- Submit as many cases as you like

- Enjoy fast sympathetic peer review and rapid publication of accepted articles

Access all the published articles

Re-use any of the published material for personal use and teaching without further permission

Customer Service

If you have any further queries about your subscription, please contact our customer services team on +44 (0) 2071111105 or via email at support@bmj.com.

Visit casereports.bmj.com for more articles like this and to become a Fellow 